\title{
Evaluation of weed changes according to different fertilization management systems, through phytosociological analyzes in lettuce and carrot
}

\author{
Elis Marina de Freitas ${ }^{1}$, Valter Carvalho de Andrade Júnior ${ }^{2}$, Evander Alves Ferreira ${ }^{3}$, Danielle Cristina \\ Fonseca Santos Grazziotti ${ }^{1}$, Amanda Gonçalves Guimarães ${ }^{1 *}$, Fernando Augusto da Silveira ${ }^{4}$, Lidiane \\ Rodrigues da Silva ${ }^{1}$, Andreia Marcilane Aker ${ }^{1}$
}

${ }^{1}$ Federal University of Jequitinhonha e Mucuri Valleys, Campus JK - Rodovia MGT 367 - Km 583, no 5000, Alto da Jacuba- CEP 39100-000, Diamantina/MG, Brazil

${ }^{2}$ Lavras Federal University, Campus Universitário, Caixa Postal 3037, CEP 37200-000, Lavras/MG, Brazil

${ }^{3}$ Federal University of Minas Gerais, Campus Regional de Montes Claros, Avenida Universitária, 1000, Universitário, CEP: 39404-547, Montes Claros/MG, Brazil

${ }^{4}$ Vicosa Federal University, Campus Viçosa, Avenida Peter Henry Rolfs, s/n, CEP: 36570-900, Viçosa/MG, Brazil

*Corresponding author: amandagguimaraes@yahoo.com.br

Abstract

The population dynamics of weeds due to different fertilization management systems is essential in the agricultural areas for the understanding of their interference and possible damages. The objective of this study was to evaluate the influence of different fertilization management systems on the weed community through phytosociological analyzes in lettuce and carrot crops grown in succession. The experimental design was a randomized block design, with eight treatments and four replications in each plant, following the same experimental layout. The treatments, referring to different management of fertilization were: Conventional; With Weeds; No Weeds; Compound; Crotalaria; Crotalaria more Compound; Lab-Lab and Lab-Lab + Compound. During cultivataion of lettuce and carrot, we collected more than 3,000 weed specimens, representing 25 species distributed in 11 families, $88 \%$ dicotyledonous and $22 \%$ monocotyledonous. The weed families with the highest value of importance in all stages of collection were Asteraceae, Brassicaceae and Poaceae. The most representative species in the area were Eleusine indica, Cyperus rotundus L., Galinsoga parviflora, Richardia brasiliensis, Oxalis latifolia, Cynodon dactylon and Conyza canadensis. The different forms of fertilization and use of cover crops were able to promote changes in the weed community and decrease in the population density during the experimental period. The treatments contributed to reduce the daily amplitudes of thermal and water changes and the incidence of sunlight on the surface layer of the soil, delaying the emergence of these weeds and contributing to other soil benefits inherent to the use of each type of fertilization.

Keywords: hedge plants, lettuce, carrot, greenery, compost.

Abbreviations: UFVJM_Federal University of Jequitinhonha e Mucuri Valleys; Den_Density; Der_Relative density; Fre_frequence; Frr_Relative frequence; Abu_abundance; Abr_Relative abundance; IVI_Importance value index

Introduction

In crop management studies, evaluations of weed dynamics and the impacts caused by the practices used in their control are fundamental to understand the interference and damage caused in agricultural areas. The presence of weeds is one of the factors that most compromises the environment in the growing areas, resulting in reductions in the production and quality of the final product. The weed species require the same factors that are also essential the cultivated crops for their development. Therefore, they establish a competitive process, when they develop with crops (Meneckelli et al., 2016). The establishment of a weed community depends on several factors, related to the crop (cultivated species, cultivar and spacing), the weed community (specific composition, density and distribution) and the environment (climate, soil and crop management) (Pitelli, 1985). Therefore, the negative effects caused by the presence of these plants should not be attributed exclusively to competition, but rather to environmental pressures, which may be direct (competition, allelopathy, crop interference and others) and indirect (relation to pest insects, diseases and others) (Karam et al., 2006). In this way, it is important to invest in methods that help in the knowledge of these communities, so that they provide the culture with better conditions for growth and development and, at the same time, unfavorable to germination, emergence and addition of weeds. Thus, as a sustainable alternative has been increasingly recommended for weed 
management and practices that promote conservation and improve the environment in a continuous way, maintaining ecosystem equilibrium (Borges et al., 2014). From the practices, the use of organic fertilizers and the cultivation of plants for the purpose of generating living and or dead cover for protection of the soil (straw), known as hedge plants can be highlighted (Silva et al., 2009; Correia et al al., 2013). These cover crops provide soil benefits, since they protect against the impact of raindrops, improve their structure the water infiltration capacity, favor nutrient cycling and cause changes in the weed population (Borges et al., 2014).

To analyze the dynamics of growth and occupation of infested communities on the impact of management systems phytosociological indexes are sometimes used (Concenço, 2015; Pitelli, 2000). These were so important in the production areas, but were intentional to identify the intensity, frequency and dominance, and consequently, favor the choice of the best times and weed management strategies for each agro-ecosystem (Pitelli, 2000; Carvalho et al., 2007).

Researches on different forms of fertilization to assist in weed management are still incipient, evidencing the need for more consistent information in this regard. The population dynamics of weeds due to different fertilization management systems is essential in the agricultural areas for the understanding of their interference and possible damages. In addition, economic, social and ecological pressures to limit the use of chemical pesticides in production systems are currently driving research in the search for alternative procedures that promote less environmental and social impact.

In this context, it is expected that more conservationist practices, such as less soil rotation, the maintenance of its cover with plants and organic fertilization can reduce the density of weeds in olive crops in a way harmful to the environment. Thus, in the present work, we tried to evaluate the influence of different fertilization management systems on the weed community through phytosociological analyzes in lettuce and carrot crops. Thus, providing information that can be used more practically in the management of weeds is useful, aiming to reduce the use of herbicides and contributing positively to a more sustainable management.

\section{Results and discussion}

In the weed community in the studied area, 25 species were identified in the different treatments, distributed in 11 botanical families: Asteraceae (nine species), Brassicaceae (three species), Poaceae, Oxalidaceae and Amaranthacea (two species each) and Cyperaceae, Lamiaceae, Rubiaceae, Brassicaceae, Caryophylaceae, Commelinacea, Portulacaceae (one species each) (Table 1 ). There was a greater predominance of families of dicotyledonous plants (88\%) than monocotyledons (22\%) in population weed species (Table 1).

The weed families found in this study resemble those identified in the soybean crop (Benedetti et al., 2009), cassava (Marques et al., 2010; Cardoso et al., 2013) and coffee (Maciel et al., 2010). The first three authors reported that the Asteraceae family was the owner of a large number of species. Maciel et al. (2010) performed a phytosociological survey on organic coffee plant and found similar results like this study on Poaceae weed family.

The high number of families of dicotyledon weeds was also verified by Cunha et al. (2016) who found that $66 \%$ of dicotyledonous weeds were cultivated in conventionally cultivated papaya. Evangelista et al. (2015) studied spontaneous plants in vegetables grown on organic system and found eight families of dicotyledonous class and two monocotyledons.

It was observed that although dicotyledons had a higher occurrence than monocotyledons, they had higher percentages of quantified individuals such as grasses and cyperaceae. This is because most of them are C4 plants with narrow leaves and deeper root system, presenting greater initial competitiveness. These plants are adapted to environmental conditions such as high light intensity, high temperature and drought (Christin et al., 2014), except for the Amarantus sp. species, which does not have the above mentioned characteristics common to most $\mathrm{C} 4$ species.

In the initial periods of coexistence, the species that had higher densities were Cyperus rotundus, Eleusine indica and Cynodon dactylon (Fig. 1). In the evaluation period before planting of crops, it was verified that besides the species Cyperus rotundus there was an increase in the number of plants of Galinsoga parviflora and Oxalia latifolia. For the evaluation period after lettuce planting, the species with the highest density was Oxalia latifolia, followed by the species Cyperus rotundus. In the last evaluation period, after planting the carrot, Cyperus rotundus remained the species with the highest density of weeds, followed by Galinsoga parviflora, Oxalis latifolia and Conyza canadensis.

The above-mentioned species, found in the initial period of coexistence, also presented representativeness in onion (Soares et al., 2004), okra (Santos et al., 2010; Bachega et al., 2013) and eggplant. These species may have been benefited at the beginning of cultivation because they have more available environmental factors, such as water, high temperature, light and naked soil. In this initial evaluation period (Fig. 7), temperatures varied between 15 and 29ㅇ, with low precipitation in the area and high relative humidity, conditions. In such conditions C4 species can develop better compared to $\mathrm{C} 3$, since they present fast initial growth and vigorous canopy, making them highly competitive with higher rates of photosynthesis (Christin et al., 2014).

For the periods after planting lettuce and carrot, we observed that condition more favored the development of C3 species. This may have occurred due to the shading caused by the crops and also to the milder temperatures in these evaluation periods, since C3 species are favored by lower availability of radiation (Christin et al., 2014).

During the evaluation periods, there was a decrease in the density of weed species. For example, density of Cyperus rotundus as the species with the highest density was dropped (Fig. 1). Kumar et al. (2012) reported that in natural infestations of weeds, Cyperus rotundus appears in larger numbers. However, in contact with other weeds, grasses or broad leaves, its vigor and growth can be reduced by the pressure of other species. Thus, in the experimental area, when the crops were planted, they shaded the area, hindering the development of this species.

The density of weeds in the initial period of coexistence was the period that presented the highest values in all the 
treatments (Fig. 2). This is due to the competition effects of weeds in the early stage of the crop development cycle, which with early germination will be able to compete for the resources of the environment, hampering development and productivity (Meneckelli et al., 2016). In this aspect, weeds with greater vegetative canopy become dominant and can develop better in the area, becoming a major problem for the development of crops. On the other hand, weeds with lower vegetative canopy are suppressed or die, leading to crops advantage over their development. It should be noted that in the initial period of evaluation, there was still no crop planting and neither the plots that would be applied to the chemical fertilizers. So, it had low weed density in relation to the treatments that used in the plots with same source of soil nutrient availability. In the plots with cover crops as treatments, they were still under development in this period, having no effect as a soil cover. However, the legumes used as cover plants may have presented higher values of weeds, due to the potential of these species used as a source of nutrients for the soil. This is because the crotalaria forms symbiotic association with soil bacteria (rhizobia) and takes advantage of the nitrogen fixed in the air by these microorganisms, providing a reduction in the need for nitrogen fertilizer application (Pereira et al., 2005). This may have contributed to better development.

However, the high density observed for the weed treatment (Fig. 2) may have occurred due to the presence of the weed communities in the area, since these were kept as cover in the plots. They have ability to regrow faster than other treatments, for example in the treatments, in which weeds were removed from the plots during the control. Development of weeds may only seem beneficial to the crop if they can be considered as cover plant.

Galvão et al. (2013) showed that the system of organic weeding of lettuce on straw of weeds is efficient for providing superior productivity and less requirement in organic fertilization. Bezerra et al. (2004) reported the efficacy of weeds in reducing agricultural pests. Sakonnakhon et al. (2006) favored the biomass and nutrients cycling by weeds with improvements in soil physical conditions.

It was verified that all the treatments contributed to the reduction of weeds in the area. The fertilizations caused physical changes in the soil, which delayed the emergence of weeds. In addition, they provided favorable environmental conditions for weed control, such as reduction of daily amplitudes of thermal and water changes and the incidence of sunlight on the surface layer of the soil. This reduction has a great impact on the germination of seeds of invasive plants, which occur in olive groves, thus contributing directly to their control (Pitelli, 1985).

Weed species that presented the highest phytosociological indexes (relative frequency, relative abundance, relative species dominance and importance value index) in the area in the evaluation period prior to planting of crops were Cyperus rotundus, Galinsoga parviflora, Oxalis latifolia, Eleusine indica, Conyza canadensis, Cynodon dactylon and Richardia brasiliensis (Fig. 3). In general, it was observed that in the treatments with cover crops, the $\mathrm{C} 3$ metabolic species had the highest relative frequency, relative density and relative abundance indices in the area (Fig. 3E, 3F, 3G and $3 \mathrm{H}$ ), in addition to the $\mathrm{C} 4$ species Cyperus rotundus.
Although Cyperus rotundus was a species with higher index of importance value for the treatments without the use of cover plants, it was verified that for the treatments Without weeds and With weeds, the species with C4 metabolism (Cynodon dactylon) also presented relative frequency index, relative density and relative abundance. This fact may be related to the empirical florals for the development of species with a type of photosynthetic metabolism, since the year of study was occurred in the summer, and that the type of growth was higher and the relative ratio was high (Fig. 7). Deuber et al. (2004) reported that this is an invasive species in beet culture and has also occurred in other vegetables (Zanatta et al., 2006). For the evaluation period after lettuce planting, we observed a decrease in the density of weed species and a change in the importance of the species in the area (Fig. 4). In the Conventional treatment, Cyperus rotundus and $O$. latifolia (Fig. $4 \mathrm{~A}$ ) were the species that presented the highest importance value, differently from the previous evaluation (Fig. 3A), in which Galinsoga parviflora had been the most representative species. In the CPD treatment (Fig. 4B), Cyperus rotundus remained with a high importance value index, but we observed a decrease of the C4 species, as previously identified. This difference between the number of weeds sampled can be explained by the architecture of the cultivated plants, because the plants shading more like the lettuce, discourage the emergence of weeds. For the treatment Without weeds (Fig. 4C) an increase in the importance value index of the species Cynodon dactylon was observed, and its metabolism was benefited in this treatment. For the treatments using compound (Fig. 4D, 4E and 4H) and cover plants (Fig. 4E, 4F, $4 \mathrm{G}$ and $4 \mathrm{H}$ ), a higher index value was found, mainly for Oxalis latifolia (C3 species). Its development was favored by shading, lower temperatures and better chemical and physical soil conditions. Thus, both the treatments using organic compost, and those using cover crops were beneficial for the development of these plants. The presence of organic fertilization may have contributed to the improvement of soil structure and microbiological activation. With increase in organic matter content, plant resistance to pest and disease attack, cation retention ( $\mathrm{Ca}$, $\mathrm{Mg}$ and $\mathrm{K}$ ) and the effect of soil moisture protection were increased. For the control of weeds, the effect of Crotalaria is related to the variations in the thermal and soil amplitudes. The amount of light filtered by the straw affects the dormancy and, consequently, the germination of the weeds (Borges et al., 2014). Lab-Lab, because of its indeterminate, low growth, confers greater capacity to its branches and leaves that distribute better and closer to the soil, presenting a greater capacity to smoothing the soil, forming an environment more conducive to the development of C3 plants (Favero et al., 2001). Regarding the evaluations made in the final period, after planting the carrot, we observed another change in the importance of weeds (Fig. 5). For the Conventional treatment (Fig. 5A), the species Cyperus rotundus again presented the highest importance value index and the Galinsoga parviflora was the second species with the highest importance value index. For the treatments using cover plants we observed an increase in frequency, density and relative abundance indexes for Cyperus rotundus species and also for Conyza canadensis species. 
Table 1. List of weeds found in the experimental area, identified by scientific name, family, common name, botanical classification and metabolism.

\begin{tabular}{|c|c|c|c|c|}
\hline Species & Family & Popular name & Classification & Metabolism \\
\hline Eleusine indica & Poaceae & Chicken foot & Monocotyledonou & c4 \\
\hline Cyperus rotundus & Cyperaceae & Tiririca & Monocotyledonou & c4 \\
\hline Galinsoga parviflora & Asteraceae & Buttercup & Dicotyledonou & c3 \\
\hline Bidens pilosa & Asteraceae & Picão & Dicotyledonou & c3 \\
\hline Leunurus sibiricus & Lamiaceae & Ruby & Dicotyledonou & c3 \\
\hline Richardia brasiliensis & Rubiaceae & Poaia & Dicotyledonou & c3 \\
\hline Oxalis latifolia & Oxalidaceae & Clover & Dicotyledonou & c3 \\
\hline Amarantus sp. & Amaranthacea & Caruru & Dicotyledonou & c4 \\
\hline Cynodon dactylon & Poaceae & Silk grass & Monocotyledonou & c4 \\
\hline Siegesbeckia orientalis & Asteraceae & Buttercup & Dicotyledonou & c3 \\
\hline Conyza canadensis & Asteraceae & Buva & Dicotyledonou & c3 \\
\hline Taraxacum officinale & Asteraceae & Dandelion & Dicotyledonou & c3 \\
\hline Coronopus didymus & Brassicaceae & Mastruço & Dicotyledonou & c4 \\
\hline Lepidium virginicum & Brassicaceae & Mastruço/mentruz & Dicotyledonou & c3 \\
\hline Raphanus raphanistrum & Brassicaceae & Nabiça & Dicotyledonou & c3 \\
\hline Stellaria media & Caryophylaceae & Finch herb & Dicotyledonou & c3 \\
\hline Commelina benghalensis & Commelinacea & Ragged & Dicotyledonou & c4 \\
\hline Portulaca oleracea & Portulacaceae & Purslane & Dicotyledonou & cam \\
\hline Chenopodium ambrosioides & Amaranthacea & Herb of Santa Luzia & Dicotyledonou & c3 \\
\hline Ageratum conyzoides & Asteraceae & Mentrasto & Dicotyledonou & c3 \\
\hline Bidens subalternans & Asteraceae & Black picket & Dicotyledonou & c3 \\
\hline Emilia fosbergii & Asteraceae & False mountain & Dicotyledonou & c3 \\
\hline Parthenium hysterophorus & Asteraceae & Losna & Dicotyledonou & c3 \\
\hline Sonchus oleraceus & Asteraceae & Milkweed & Dicotyledonou & c3 \\
\hline Oxalis corniculta & Oxalidaceae & Trevinho & Dicotyledonou & c3 \\
\hline
\end{tabular}

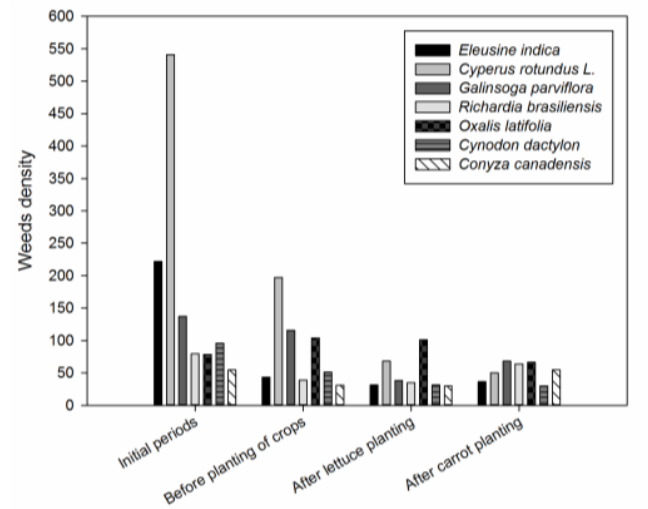

Fig 1. Relationship between weed density and coexistence period of the most representative species of the experimental area.

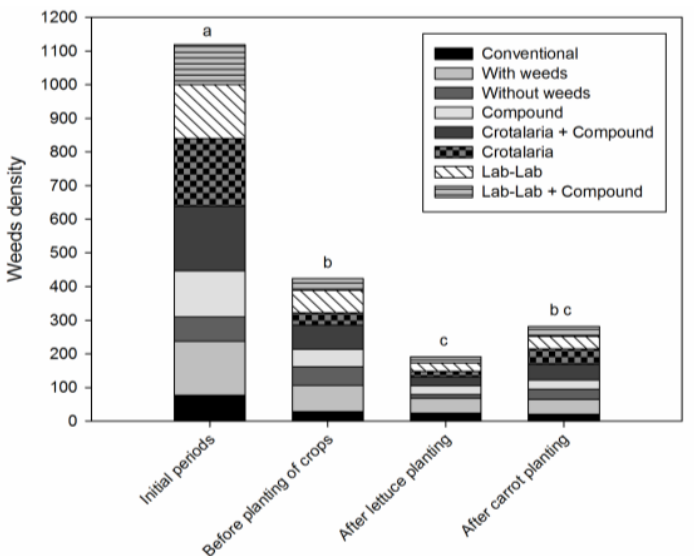

Fig 2. Density of weeds for the different periods of coexistence of plants of each treatment. The treatments with equal letters do not present significant difference according to the Tukey test $(p<0.05)$. 

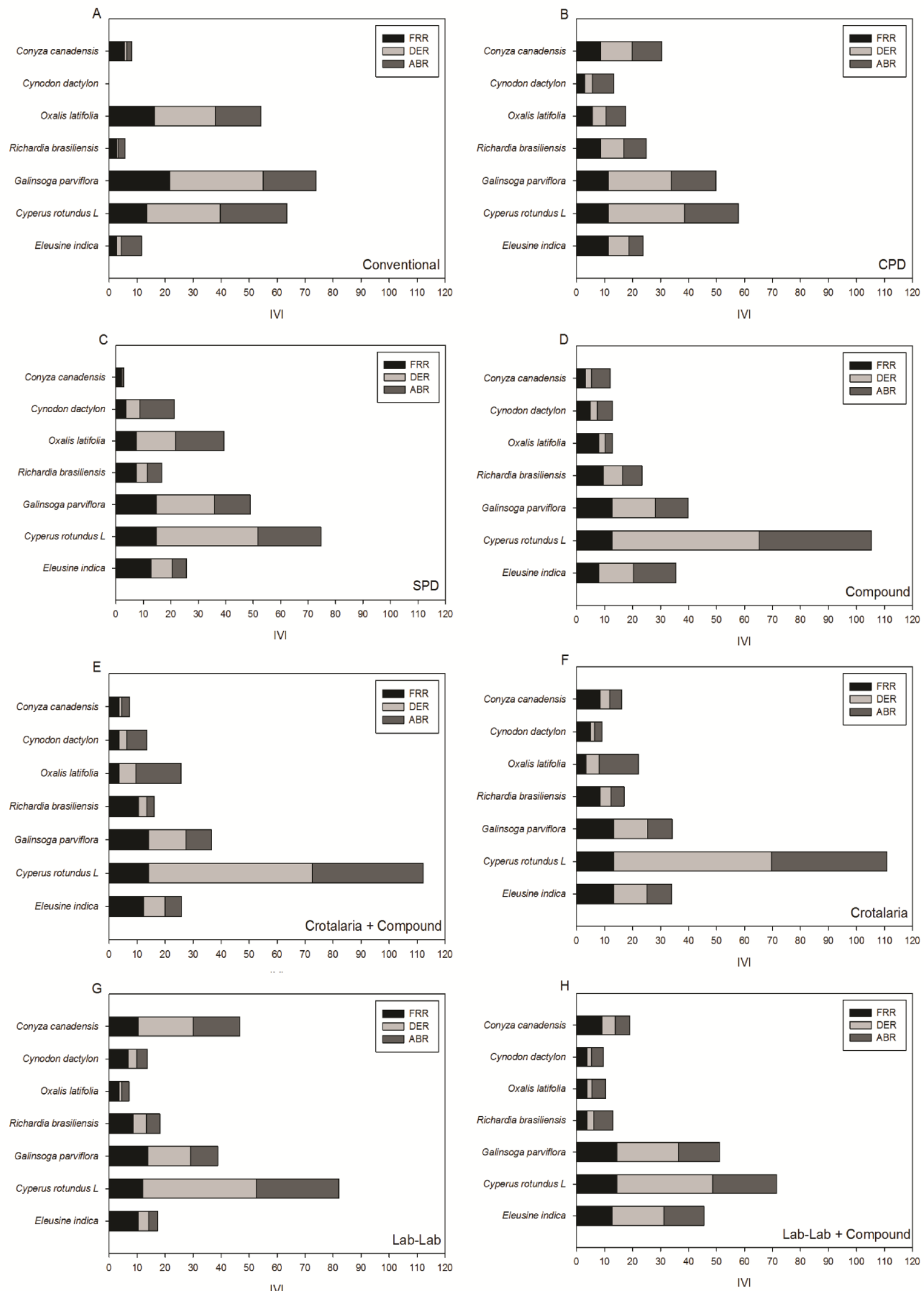

Fig 3. Relative frequency (FRR), relative density (RER), relative abundance (ABR) and importance value index (IVI) of weeds prior to planting of lettuce, according to treatments: (A) Conventional; (B) CPD- with weeds; (C) SPD- without weeds; (D) Compound; (E) Crotalaria + Compound; (F) Crotalaria; (G) Lab-Lab + Compound; and (H) Lab-Lab. 

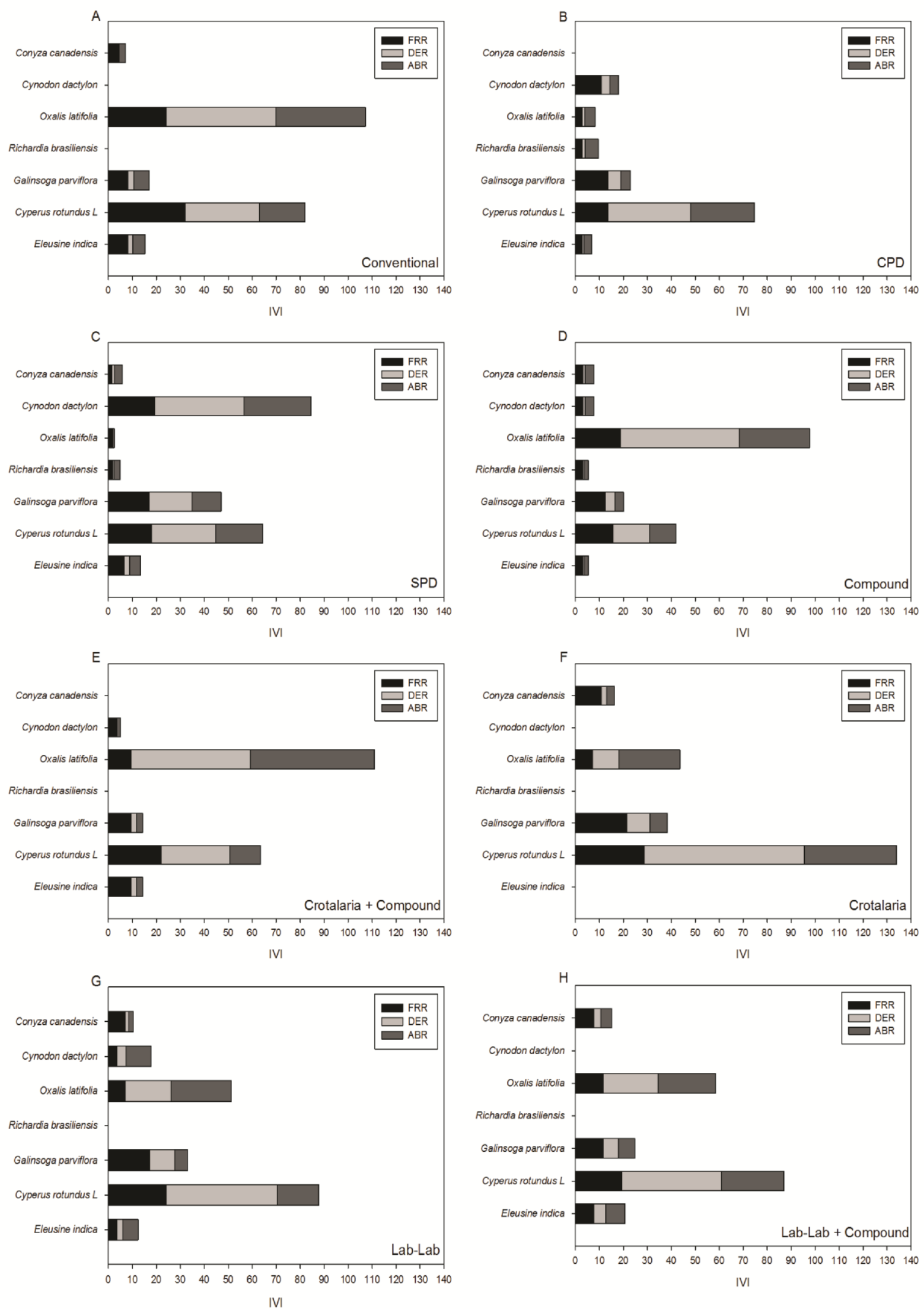

Fig 4. Relative frequency (FRR), relative density (RER), relative abundance (ABR) and importance value index (IVI) of weeds after planting lettuce, according to the treatments: (A) Conventional; (B) CPD- with weeds; (C) SPD- without weeds; (D) Compound; (E) Crotalaria + Compound; (F) Crotalaria; (G) Lab-Lab + Compound; and (H) Lab-Lab. 

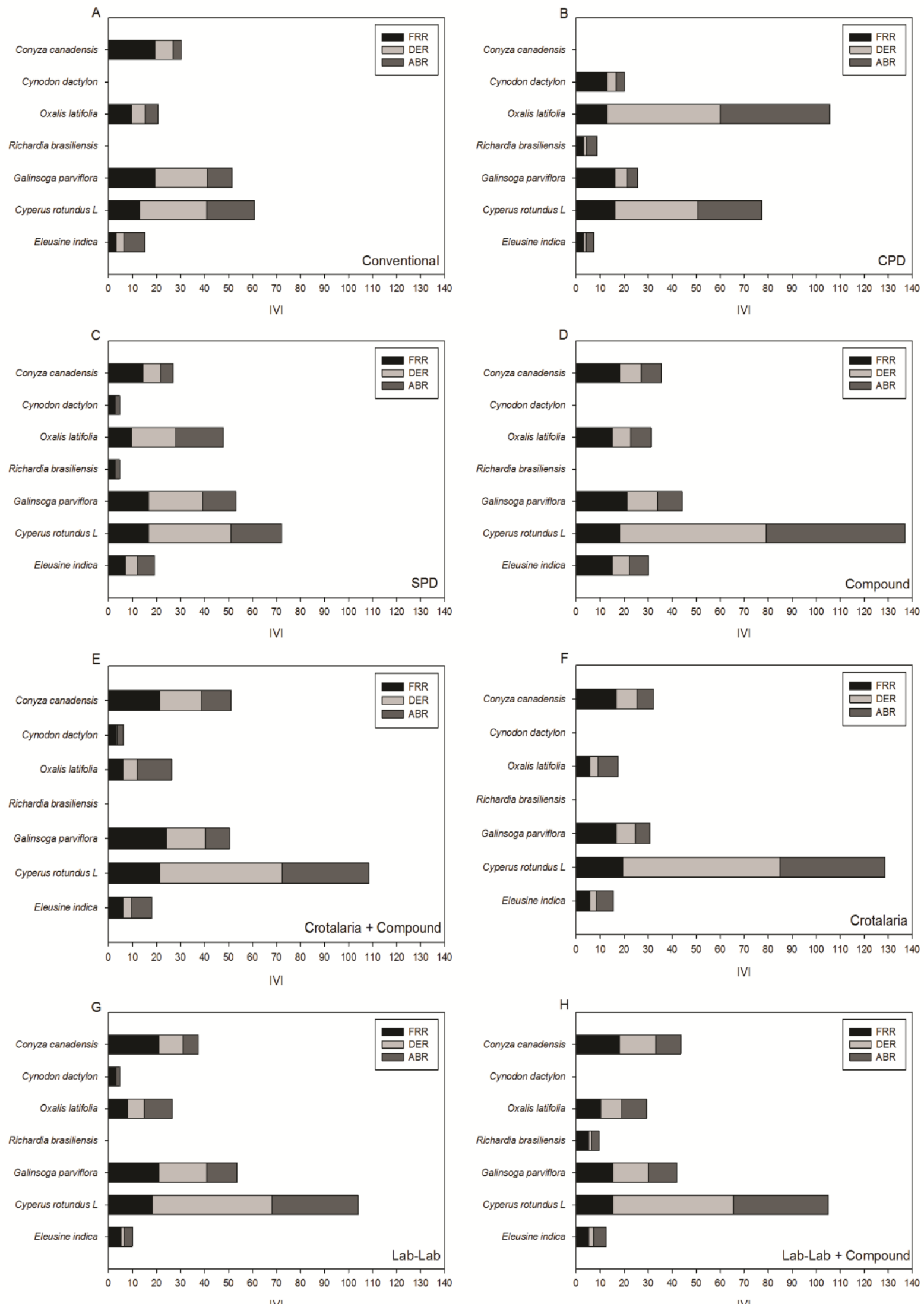

Fig. 5. Relative frequency (FRR), relative density (RER), relative abundance (ABR) and importance value index (IVI) of the weeds after planting the carrot, according to the treatments: (A) Conventional; (B) CPD- with weeds; (C) SPD- without weeds; (D) Compound; (E) Crotalaria + Compound; (F) Crotalaria; (G) Lab-Lab + Compound; and (H) Lab-Lab. 




A

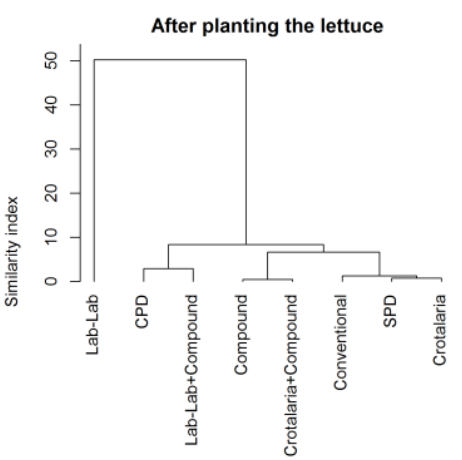

B

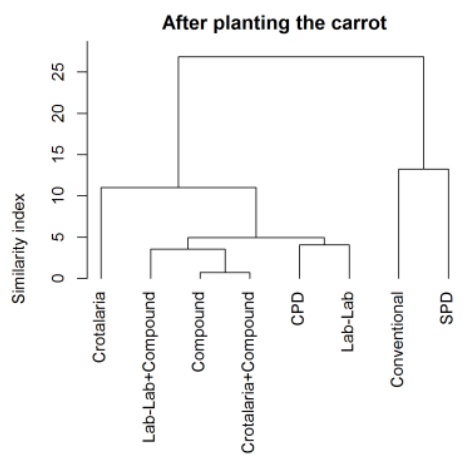

C

Fig 6. Similarity index among the eight treatments (Areas) in the different evaluation periods. (A) Before planting crops; (B) After planting the lettuce; (C) After planting the carrot.

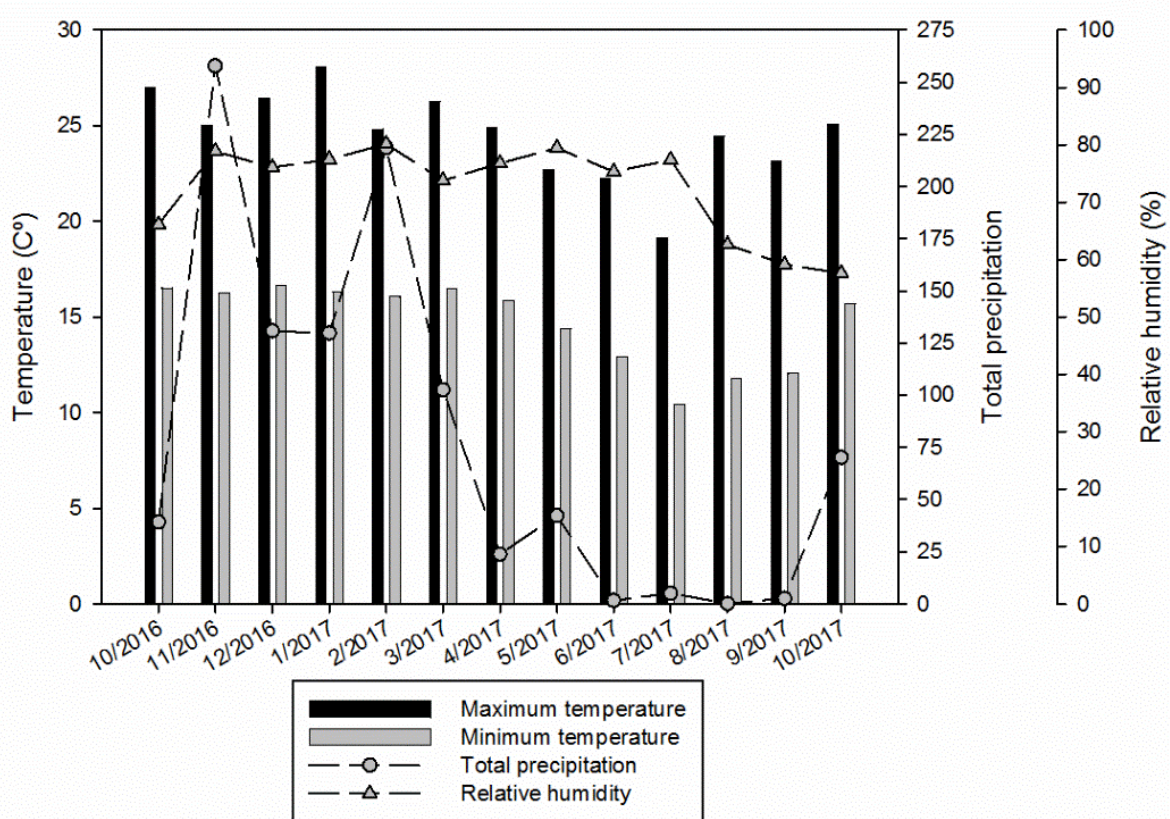

Fig 7. Maximum, minimum temperature, total precipitation and relative humidity of the experimental area during the work period of conduction.

This fact could have occurred due to climatic and environmental conditions favorable to the development of these species and also to the power of covering the soil of the legumes used. It is known that cover crops provide improvements in the chemical and physical conditions of the soil and that when using the resources of the medium for its growth can reduce the development and the production of weeds seeds, contributing to the exhaustion of the seed banks (Borges et al., 2014).

For all evaluated periods and among the species identified in each treatment, $C$. rotundus was the one that presented the highest value of importance in all surveys, being the most representative species in this study. Species of the genus Cyperus have a great competitive capacity, being able to affect several cultures (Monquero, 2014). It presented wide adaptation and good dissemination, found in all types of soil and climate, having both sexual and asexual reproduction (Panozzo et al., 2009). These factors are well evidenced in the present work, since the genus was present in all treatments, noting that the high relative density of this species in the different treatments may be related mainly to its biology, which may have been benefited by environmental conditions.

In a given crop, it is difficult to estimate which species of weeds were most damaging to the crop, but it is assumed that those with the highest phytosociological indexes are the most problematic. Uusually in a community, all species cannot present the same intensity in the interference imposed on the crop development. Therefore, we verified that Cyperus rotundus, Galinsoga parviflora and Oxalis latifolia were the species with the highest numerical representativity in almost all the evaluations made in the different periods. It shows that for these species, greater attention should be paid to the management and control, because they can even make farming unfeasible in the infested area.

The treatments that had the greatest similarity in the period before planting the crops according to the floristic similarity index were with weeds and Lab-Lab (Fig. 6A), as previously seen, these treatments showed very close plant densities. At the same time, the lowest species similarity was observed for the Conventional and Crotalaria treatments. 
In the evaluations made after planting the lettuce (Fig. 6B), it was verified that the greatest similarity of species occurred for the treatments Compost and Crotalaria + Compost. The treatments that presented the lowest similarity of species were the Conventional and Lab-Lab treatments. After the sowing of the carrot, there was a higher species similarity (Fig. 6C) for the treatments Compost and Crotalaria + Compost. Conventional and Crotalaria treatments had the lowest species similarity.

According to Carvalho and Pitelli (1992), similarity indexes are not only related to the soils or the distance between areas, but also to the forms of management used in these areas. These changes may influence the germination and development of weeds and, consequently, weed management strategies considered more important. It should also be emphasized that the similarity index is usually calculated according to the individual species present.

Thus, it was observed that the highest similarity throughout the evaluations were occurred for the treatments Compost and Crotalaria + Compost, evidencing that the management of fertilization of these treatments may have aided in the emergence of similar weeds, besides the effects of the crops, since these results were obtained in post-planting evaluations of lettuce and post-planting of the carrot.

Therefore, this study was able to provide more information about the weed community through the evaluation of phytosociological parameters, along with the evaluation of weed density and similarity. It is possible to perceive differences of emergence of weed species according to different season and fertilization management in lettuce and carrot crops in succession.

\section{Materials and methods}

\section{Plant materials}

Two different cultures, carrot and lettuce, were used for the experimental trial. The cultivar of lettuce was Veneranda, which is characterized as tolerant to the LMV virus, early tillage and edge burning. The carrot cultivar used was Nantes Milena, which is characterized as fall/winter cultivar, cylindrical in shape, dark orange and high in carotene content.

\section{Treatments}

The treatments represent the use of different management of fertilization in lettuce and carrot crops, in succession. The management of the fertilizers consisted of organic fertilizers (organic compost), minerals (mineral fertilizer) and green manure (legume residues), totaly eight treatments:

i. Treatment 1 (T1) = Conventional fertilization according to technical recommendations for lettuce and carrot cultivation, according to the ' 5 a aproximação' (Ribeiro, 1999);

ii. Treatment $2(\mathrm{~T} 2)=$ With weeds, without fertilization and control of weeds only in the crop lines, remaining in the soil in the surrounding area;

iii. Treatment $3(\mathrm{~T} 3)=$ No Weeds, control treatment, without fertilization and weed control in all areas;

iv. Treatment $4(\mathrm{~T} 4)=$ Compound, organic fertilizer, having as feedstock quail bed and crushed dry grass (1:10); v. Treatment 5 (T5) = Crotalaria + Compost, use of Crotalaria juncea as soil cover plant and compost as organic fertilizer;

vi. Treatment $6(\mathrm{~T} 6)=$ Crotalaria, with the use of the leguminous species Crotalaria juncea as ground cover plant;

vii. Treatment $7(\mathrm{~T} 7)=$ Lab-Lab, using the leguminous species Lab-Lab purpureus as a soil cover plant; and,

viii. Treatment 8 (T8) = Lab-Lab + Compound, using L. purpureus as a soil cover plant and the compound as organic fertilizer.

\section{Experimental design and assay}

The experiment was conducted from October 2016 to November 2017 in the experimental field area of the Juscelino Kubitschek Campus, Federal University of the Jequitinhonha and Mucuri Valleys (UFVJM), in Diamantina/MG - Brazil, located at 1812'01 "S, 4336'20"W at $1,400 \mathrm{~m}$ altitude.

The climate of the region is characterized as temperate humid, with dry winter with mild temperatures and mild summer with more rainy periods. The average annual precipitation is approximately $1,404 \mathrm{~mm}$ with a rainy period from October to March, when $88 \%$ of the precipitate total occurs during the year. The minimum and maximum temperatures found during the experiment were $14.1^{\circ} \mathrm{C}$ and $23.7^{\circ} \mathrm{C}$, respectively (Fig. 7). The soil of the experimental area is classified as Quarantine Neosol (Santos et al., 2013), with $83 \%$ sand, $10 \%$ clay and $7 \%$ silt.

The experiment in the field was conducted in a randomized complete block design with four replications. Each replicate contained eight crop lines (beds) to allocate the eight treatments spaced $0.5 \mathrm{~m}$ apart, with each plot containing 1.0 $\mathrm{m}$ wide and four rows $5 \mathrm{~m}$ long.

Before the implementation of the field experiment, the lettuce seedlings were previously produced by the direct sowing method in styrofoam trays in inverted pyramid format, containing 128 cells with commercial substrate under greenhouse conditions, with three lettuce seeds per cell. After emergence, one seedling was maintained per cell, being able to transplant in the field when they had 4 to 6 leaves (approximately 30 days).

The lettuce seedlings were planted in the field, with spacing of $0.25 \times 0.25 \mathrm{~m}$, totaly 80 plants per plot. After 66 days, their harvesting was performed. After the lettuce was harvested, the carrot was planted directly in the beds, in grooves in the direction of the width of the bed with depth of $1 \mathrm{~cm}$. The grooves used for the sowing of the carrot were made with spacing's of $25 \mathrm{~cm}$, where the seeds were evenly distributed. After 25 days of sowing, thinning was done in the crop, leaving a spacing of $6 \mathrm{~cm}$ between the plants. The carrot harvest was occurred on October 4, 2017, 96 days after sowing.

Ten days before transplanting of lettuce seedlings in to the field and after the fallow period of cover plants used, the fertilization of planting was carried out with NPK and more organic fertilization with bovine manure $\left(50 \mathrm{t} \mathrm{ha}^{-1}\right)$ and cover fertilizations with $\mathrm{N}$ and $\mathrm{K}_{2} \mathrm{O}$ at 15,30 and 40 days. For the treatment with Weeds, the area was maintained with weeds as vegetation cover, and for the treatment Without Weeds, these plants were totally removed from the area. In the treatment of organic compost, $6 \mathrm{~L} \mathrm{~m}^{-2}$ of organic compost was applied to the plot. Crotalaria juncea (Crotalaria) and 
Lab-lab purpureus (Lab-Lab) legumes were used for the treatments with the use of plants as plant cover, and these were planted according to Embrapa's recommendations (2014), at depths of 2 to $3 \mathrm{~cm}$, with spacing between the grooves of $20 \mathrm{~cm}$ and density of 40 seeds per linear meter of groove. When these species presented $50 \%$ flowering, they were cut close to the soil and arranged on the beds, without incorporation in to the soil. The legumes were left fallow in the beds for approximately 30 days. After that period, it was transplanted with lettuce seedlings. When the treatment was the organic compound with some leguminous, the compound was applied to the soil only at the time of planting the green manures, and after the flowering of these, they were cut close to the soil and placed as mulch and reapplied again as the organic compound, $6 \mathrm{~L} \mathrm{~m}^{-2}$.

\section{Weed community assessment}

The phytosociological study was carried out every 20 days, from the sowing period of the cover crops until the carrot harvest period. Before the consolidation of the experiment, weeds were sampled in the total area. The classification was based on the Angiosperm Phylogeny Group III (2009) system, with assistance in the delimitations of families and the ordering of some genera, according to Souza and Lorenzi (2005). In addition, specific literature was used to identify and quantify weed species present in any experimental area (Kissman and Groth, 2000; Lorenzi, 2008), as well as bibliographies of medicinal plants, ornamental plants, dissertations and theses related to the subject.

For each treatment, weed samples were collected using a $0.25 \mathrm{~m}^{2}$ area, cast randomly twice in each plot (BraunBlanquet, 1979; Erasmo et al., 2004), to be identified, quantified and separated by species and families.

From the counting of the present species, the phytosociological indexes were calculated: i) Density (Den): total number of individuals per species/total area collected; (ii) Relative density (Der): density of species x 100/total frequency of all species; iii) frequency (Fre): number of parcels containing species/total number of parcels used; iv) relative frequency (Frr): species frequency $x$ 100/total frequency of all species; $v$ ) abundance (Abu); total number of individuals per species/total number of plots with the species; vi) relative abundance (Abr): abundance of species $x$ 100/total abundance of all species; vii) Import Value Index (IVI): Frr + Der + Abr.

For the evaluation of the weed community in the area, the different periods of development of the experiment were considered, so the periods evaluated were separated into four: i) period prior to planting of the crops, when the treatments had not yet been applied in the area; ii) period prior to lettuce planting, referring to the development period of the cover plants; iii) period after the planting of lettuce; and iv) period after planting the carrot.

\section{Statistical analysis}

The Shapiro-Wilk test $(p<0.05)$ and analysis of variance was performed according to the F-test for all treatments $(p<$ $0.05)$, considering the block design and analysis in time subdivided plots. After detecting the significance of the treatments, the averages were compared using the Tukey test at $5 \%$ level of significance.

In order to compare weed communities established in each evaluation period, considering each treatment group distinctly, the Sorensen floristic similarity index (Ss) was used: $2 a /(2 b+b+c)$, where: $a=$ number of species common to both plots or communities; $b=$ number of species occurring in plot 2 or community 2; and, $c=$ number of species occurring in plot 1 or community 1 . After that, a twodimensional diagram (dendrogram) was constructed, using the middle link method (UPGMA) as hierarchical grouping method and the distance measure was Euclidian. All statistical analyzes were performed using the $R$ ( $R$ Core Team, 2017) software.

\section{Conclusion}

The main weed species found in all evaluation periods were Eleusine indica, Cyperus rotundus, Galinsoga parviflora, Richardia brasiliensis, Oxalis latifolia, Cynodon dactylon and Conyza canadensis. Cyperus rotundus was the species with the highest phytosociological indexes, being characterized as the weed with the greatest potential of competition with the lettuce and carrot crops, under different management of fertilization. In the studied olive cultivation, there was a predominance of dicotyledonous weeds, although monocotyledonous species had higher species density. It was verified that the cultivation and the use of cover crops contributed to the reduction of weed infestation in lettuce and carrot crops, and are therefore recommended for use in the control and suppression of weeds in olive groves.

\section{Acknowledgment}

We thank CNPq and Fapemig agencies for the provision of financial resources and grants for the development of the project. The present work was carried out with the support of the Coordination of Improvement of Higher Education Personnel - Brazil (CAPES) - Financing Code 001.

\section{References}

Angiosperm Phylogeny Group (2009) An update of the Angiosperm Phylogeny Group classification for the orders and families of flowering plants: APG III. Bot J Linn Soc. 161 (2): 105-121.

Bachega LPS, Carvalho LB, Bianco S, Cecilio Filho AB (2013) Períodos de interferência de plantas daninhas na cultura do quiabo. Planta Daninha. 31 (1): 63-70.

Benedetti JGR, Alves PLCA, Yamauti MS (2009) Período anterior à interferência de plantas daninhas em soja transgênica. Sci Agrar. 10 (4): 289-295.

Bezerra MS, Oliveira MRV, Vasconcelos SD (2004) Does the presence of weeds affect Bemisia tabaci (Gennadius) (Hemiptera: Aleyrodidae) infestation on tomato plants in a semi-arid agro-ecosystem. Neotrop Entomol. 33 (6): 769-775.

Borges WLB, Freitas RS, Mateus GP, Sá ME, Alves MC (2014) Supressão de plantas daninhas utilizando plantas de cobertura do solo. Planta daninha. 32 (4): 755-763.

Braun-Blanquet J (1979) Fitossociologia: bases para el estudio de las comunidades vegetales. Madrid: H. Blume, 820p.

Cardoso AD, Viana AES, Barbosa RP, Teixeira PRG, Cardoso Júnior NS, Fogaça JJNL (2013) Levantamento fitossociológico 
de plantas daninhas na cultura da mandioca em Vitória da Conquista, Bahia. Biosci J. 29 (5): 1130-1140.

Carvalho SL, Pitelli RA (1992) Levantamento e análise fitossociológica das principais espécies de plantas daninhas de pastagens da região de Selvíria (MS). Planta Daninha. 10 (1/2): 25-32.

Carvalho LB, Bianco S, Pitelli RA, Bianco MS (2007) Estudo comparativo do acúmulo de massa seca e macronutrientes por plantas de milho var. BR-106 e Brachiaria plantaginea. Planta Daninha. 25 (2): 293-301.

Concenço G (2015) Análises fitossociológicas de plantas daninhas: método aplicado ao ambiente" R". Embrapa Agropecuária Oeste-Documentos (INFOTECA-E).

Correia NB, Leite MB, Fuzita WE (2013) Consórcio de milho com Urochloa ruziziensis e os efeitos na cultura da soja em rotação. Biosci J. 29 (1): 65-76.

Christin PA, Arakaki M, Osborne CP, Braeutigam A, Sage RF, Hibberd JM, Kelly S, Covshoff S, Wong GKS, Hancock L, Edwards EJ (2014) Shared origins of a key enzyme during the evolution of C-4 and CAM metabolism. J Exp Bot. 65 (13): 3609-3621.

Cunha JLXL, Freitas FCL, Coelho MEH, Silva MGO, Silva KS, Nascimento PGML (2016) Fitossociologia de plantas daninhas na cultura do pimentão nos sistemas de plantio direto e convencional. Revista Agro@mbiente. 8 (1): 119-126.

Deuber R, Soares Novo MCS, Trani PE, Araújo RT, Santini A (2004) Manejo de plantas daninhas em beterraba com metamitron e sua persistência em argissolo. Bragantia. 63 (2): 283-289.

Embrapa Hortaliças. Distribuição da produção de hortaliças no Brasil. 2011. Disponível em: <http://www.cnph.embrapa.br/paginas/hortalicas_em_ numeros/ hortalicas_em_numeros.htm>. Acesso em: 19 jul. 2014.

Erasmo EAL, Azevedo WR, Sarmento RA, Cunha AM, Garcia SLR (2004) Potencial de espécies utilizadas como adubação verde na gestão integrado de plantas daninhas. Planta Daninha. 22 (3): 337-342.

Evangelista MO, Albuquerque JAA, Santos SV, Alves JMA, Santos TS, Castro TS, Neto FA (2015) Fitossociologia de plantas espontâneas em produção orgânica de hortaliças no estado de Roraima. Sodebras. 117: 259-266.

Favero C, Jucksch I, Alvarenga RC, Costa LM (2001) Modificações na população de plantas espontâneas na presença de adubos verdes. Pesq Agropec Bras. 36 (11): 13551362.

Galvão RO, Araújo Neto SE, Ferreira RLF (2013) Plantio direto orgânico de alface sobre cobertura viva e morta e adubada com composto. Revista ACSA. 9 (3): 75-80.

Karam D, Melhorança AL, Oliveira MF (2006) Plantas Daninhas na Cultura do Milho. Ministério da Agricultura, Pecuária e Abastecimento. Sete Lagoas.

Kissmann KG, Groth D (2000) Plantas infestantes e Nocivas: Tomo III. 2rd. São Paulo: BASF, 722p.

Kumar M, Das TK, Yaduraju NT (2012) An integrated approach for management of Cyperus rotundus (purple nutsedge) in soybean-wheat cropping system. Crop Prot. 33: 74-81.

Lorenzi H (2008) Plantas daninhas do Brasil: terrestres, aquáticas, parasitas e tóxicas. 4rd. Nova Odessa: Plantarum. 640 p.
Maciel CD, De G, Poletine, JP, Oliveira Neto AM, De Guerra N Justiniano W (2010) Levantamento fitossociológico de plantas daninhas em cafezal orgânico. Bragantia. 69 (3): 631-636.

Marques LJP, Silva MRM, Araújo MS, Lopes GS, Corrêa MJP, Freitas ACR, Muniz FH (2010) Composição florística de plantas daninhas na cultura do feijão-caupi no sistema de capoeira triturada. Planta Daninha. 28:Especial.

Marques LJP (2015) Períodos de interferência das plantas daninhas na cultura da berinjela 'Nápoli' sem tutoramento e desbrota. 2015. 126 f. Tese (Doutorado em Agronomia) Faculdade de Ciências Agrárias e Veterinárias, Universidade Estadual Paulista, Jaboticabal, SP.

Meneckelli D, Yamashita OM, De Carvalho MAC, Campos OR, Koga OS (2016). Desenvolvimento inicial de biótipos de fedegoso em função da acidez e cobertura vegetal do solo. Ambiência. 12 (2): 683-697.

Monquero PA (2014) Aspectos da biologia e manejo das plantas daninhas. São Carlos: RiMa

Panozzo LE, Agostinetto D, Galon L, Moraes PVD, Pinto JJO, Neves R (2009) Métodos de manejo de Cyperus esculentus na lavoura de arroz irrigado. Planta Daninha.27(1), 165-174.

Pereira AJ, Guerra JGM, Moreira VF, Teixeira MG, Urquiaga S, Polidoro JC, Espindola JAA (2005) Desempenho agronômico de Crotalaria juncea em diferentes arranjos populacionais e épocas do ano. Seropédica: Embrapa Agrobiologia.

Pitelli RA (1985) Interferência de plantas daninhas culturas agrícolas. Informe Agropecuário. 11: 16-25.

Pitelli RA (2000) Estudos fitossociológicos em comunidades infestantes de agroecossistemas. J. Conserb. 1 (2): 1-7.

R Core Team (2017). R: a language and environment for statistical computing. Vienna, Austria: $\mathrm{R}$ Foundation for Statistical Computing.ro AC (1999) Comissão de fertilidade do solo do estado de Minas Gerais. Recomendações para o uso de corretivos e fertilizantes em Minas Gerais: 5a Aproximação. Viçosa: CFSEMG 360p.

Santos JB, Silveira TP, Coelho PS, Costa OG, Matta PM, Silva MB, Drumond Neto AP (2010) Interferência de plantas daninhas na cultura do quiabo. Planta Daninha. 28: 255-262.

Santos HG, Jacomine PKT, Anjos LHC, Oliveira VA, Lumbreras JF, Coelho MR, Almeida JÁ, Cunha TJF, Oliveira JB (2013) Sistema Brasileiro de Classificação de Solos. 3rd. Brasília: Embrapa, $353 p$.

Sakonnakhon SPN, Cadisch G, Toomsan B, Vityakon P, Limpinuntana V, Jogloy S, Patanothal A (2006) Weeds - friend or foe? The role of weed composition on stover nutrient recycling efficiency. Field Crops Res. 97: 238-247.

Silva PSL, Cubnha TMS, Oliveira RC, Silva KMB, Oliveira OF (2009) Controle de plantas daninhas por meio da consorciação com gliricídia: II. Cultura do milho. Plantas daninhas. 27 (1): 105-112.

Soares DJ, Gravena R, Pitelli RA (2004) Efeito de diferentes períodos de controle das plantas daninhas na produtividade da cultura da cebola. Planta Daninha. 22 (4): 517-527.

Souza VC, Lorenzi H (2005) Botânica sistemática: guia ilustrado para identificação das famílias de angiospermas da flora brasileira, baseado em APG II. Instituto Plantarum.

Zanatta JF, Figueredo S, Fontana LC, Procópio SO (2006) Interferência de plantas daninhas em culturas olerícolas. Revista da FZVA. 13 (2): 39-57. 